\title{
ИДЕОЛОГИЧЕСКАЯ БОРЬБА СОВЕТСКОЙ ВЛАСТИ ПРОТИВ БАЙСТВА КОРЕННОГО НАСЕЛЕНИЯ ГОРНОГО АЛТАЯ В ГАЗЕТЕ «КЫЗЫЛ ОЙРОТ» В 1925-1928 ГГ.
}

\section{IDEOLOGICAL STRUGGLE OF THE SOVIETGOVERNMENT AGAINST BAISTVO OF INDIGENOUS POPULATION OF GORNY ALTAI IN NEWSPAPER "KYZYL OIROT" IN 1925-1928}

\section{E. Torushev}

Summary: In 1920-s, print media became the main instrument of propaganda and agitation, as well as a means of forming mass consciousness in the Soviet Union. In this work, based on the materials of newspaper "KyzylOirot", the ideological struggle of the party against baistvo / kulaks of indigenous population of Gorny Altai is investigated. According to the newspaper "Kyzyl Oirot", Bai is a hostile alien person for the Soviet regime. It was concluded that newspaper became an instrument of propaganda against baistvo.

Keywords: Gorny Altai, Altaians, ideology, newspaper.
B 1920-х гг. в Горном Алтае печатные периодические издания СМИ - газеты становятся основным средством коммуникации, формирующие общественное мнение. В рассматриваемый период главным инструментом советской пропаганды среди коренного населения региона становится газета «Кызыл Ойрот». Именно на ее страницах начинается пропагандистская компания против байства Горного Алтая. Для исследования этого вопроса в работе в качестве источников использованы оцифрованные номера газеты «Кызыл Ойрот» являющиеся цифровым ресурсом национальной библиотеки им. М.В. Чевалкова Республики Алтай. В работе ведены материалы номеров газеты с февраля 1925 г. - начала печатания этого периодического издания - по 1928 г. - период - свёртывания новой экономической политики (НЭПа) в стране. Во время работы выяснилось, что в фонде национальной библиотеки им. М.В. Чевалкова Республики Алтай отсутствуют некоторые номера газеты «Кызыл Ойрот»: за 1925 г. - № 27, за 1926 г. - № 1, 15, 34, за 1927 г., - № 1, за 1928 г. № 24 по 49.

В статье исследованный период для нас интересен тем, что в стране в целом проводилась политика НЭПа, и зажиточные слои еще не подвергаются жестким репрессиям. Это время именно пропагандисткой компании против байства, которая разворачивается на страницах региональной партийной газете «Кызыл Ойрот».

\author{
Торушев Эркем Геннадьевич \\ К.и.н., с.н.С., БНУ РА «Научно-исследовательский \\ институт алтаистики им. С.С. Суразакова» \\ (2. Горно-Алтайск) \\ erktor@mail.ru
}

Аннотация: В 1920-х гг. в Советском Союзе печатные СМИ становятся главным орудием пропаганды и агитации, также средством формирования массового сознания. В данной работе на материалах газеты «Кызыл Ойрот» исследована идеологическая борьба партийных органов против байства/кулачества коренного населения Горного Алтая. На страницах газеты «Кызыл Ойрот» бай - это враждебный чуждый элемент для Советской власти. Сделан вывод о том, что газета стала инструментом пропаганды против байства.

Ключевые слова: Горный Алтай, алтайцы, идеология, газета, бай.

Политика дискриминационных мер к кулачеству/ байству, осуществляемая Советской властью в Горном Алтае в период НЭПа, в некоторой степени освещена в публикациях советского периода [17 35; 42]. В этих работах отмечено, что в исследуемые годы кулаки и байи были ограничены в гражданских и экономических правах. В первом случае Советская власть лишила их избирательного права. В экономическом плане кулаков и байев ограничили в кредитовании. Кредит распределялся преимущественно среди бедняков и середняков, меньше выдавался зажиточным слоям [17, с. $125 ; 35$, с. 167-168]. Также в рассматриваемые годы на зажиточные хозяйства начались налоговые давления. Партийные органы, поддерживая крестьянскую бедноту, освобождали ее от налогов. Основная доля налога перекладывалась на кулацко-байские хозяйства [42, с. 20].

Из современных работ надо отметить коллективную монографию «История Горного Алтая. В трех томах. Том второй. 1900 - 1945 гг. ». В этом опубликованном труде описаны мероприятия партийных органов в Горном Алтае в период НЭПа по ограничению кулачества и байства в гражданских, финансовых и хозяйственных сферах [27].

Если рассматривать в целом, тема взаимоотношения молодой Советской власти в Горном Алтае и местного ку- 
лачества/байства в период НЭПа недостаточно изучена, так, как исследования советского периода несли на себе серьезный идеологический отпечаток. В современных работах были освещены некоторые негативные факторы, которые умалчивались авторами в советский период. Но глубоких исследований не было проведено. И эта работа восполнит некоторые пробелы в данной теме.

В 1922 г. в Горном Алтае затихает кровопролитная гражданская война. 1 июня 1922 г. образуется Ойротская автономная область (с 1948 г. - Горно-Алтайская автономная область с 1992 г. по наши дни - Республика Алтай. Изучаемый регион находится на юге Западной Сибири, расположен в пределах Алтайских гор). По переписи 1926 г. в Горном Алтае проживали представители более 36 этносов. Из них самые многочисленны были русские 51812 (52\%), коренные жители - алтайцы 42278 (42,4\%) и казахи 2326 (2,3\%) [26, с. 12].

В 1920-х гг. проживающие в Горном Алтае этносы отличались по образу жизни, культурно-бытовому укладу и по социально-экономическому строю. Так, коренное население Ойротской автономной области в основном занималось животноводством и лесными промыслами, многие из них вели кочевой или полукочевой образ жизни. В общественном строе алтайцев преобладали патриархально-родовые отношения. В связи с чем зажиточнобайские семьи, как и ранее, продолжали доминировать в общественно-экономической жизни коренного населения. Так как многие из них являлись представителями ещё старой царской административно управленческой структуры «зайсанами, демичи, волостными управителями и т.д.» $[15$, л. 12]. Это говорит о том, что эти люди имели опыт взаимодействия с органами государства, что представляло большое значение в среде полукочевого (кочевого) населения, которое в основной своей массе были не грамотны или малограмотны, часто плохо владели русским языком.

В 20-х гг. XX в. после гражданской войны основная часть байства коренного населения Горного Алтая в экономическом плане не достигла досоветского уровня. Но в период НЭПа, когда регион стал стабильно развиваться, байство смогло частично восстановить свои хозяйства и даже увеличиться численно. Например, за пять лет (1924-1928 гг.) удельный вес среди коренного населения байской группы (хозяйства имеющие скот свыше 35 голов в переводе на крупный) возросла с 4,4 до 8,3\%, так же за этот период повысился удельный вес середняков (хозяйства имеющие скот от 11 до 35 голов в переводе на крупный) с $26 \%$ до $45,7 \%$, а бедняцкие (хозяйства имеющие скот до 10 голов в переводе на крупный) соответственно понизились с 69,6 до 46\% [26, с. 133-134, 198]. По переписи 1926 г. 1859 человек (3,2 \% самодеятельного населения Горного Алтая) можно отнести к батракам у них наемный труд являлся основным средством суще- ствования. Вместе с членами семей это группа составила 3492 человек. По национальной принадлежности более половина батраков относится к русским (59,3\%) и треть к алтайцам, а по половому составу $69 \%$ их были мужчинами и $31 \%$ женщинами [26, с. 28].

Можно констатировать, что в исследуемый период у алтайского населения сложилась двоякая ситуация, с одной стороны, в Горном Алтае установилась Советская власть во главе с областной партийной организацией и Советами. С другой, по-прежнему сильны были традиционные веками функционирующие социально-экономические отношения внутри этноса, где байство имело сильное влияние на коренное население. Надо отметить, что Советская власть Конституцией РСФСР 1918 г. лишает эксплуататорские классы, к которым относится и байство, участия в выборах в Советы. С утратой избирательного права байи теряют политические, социальные и экономические блага, предоставляемые государством [31, с. 24]. Но, не смотря на эти ограничительные меры со стороны молодой Советской власти, байи, как при царской администрации, продолжали верховодить на общественных собраниях, свой скот пасли на самых тучных и обширных пастбищах, им принадлежали лучшие сенокосы [26, с. 37-39].

Партийные руководство области понимало, что первоначальная цель НЭПа - это восстановление народного хозяйства. Затем следующим шагом будет переход страны в целом к социалистическому обществу, где не было места эксплуататорским слоям. И чтобы исключить влияния байства на остальное алтайское население, партийные функционеры начинают пропагандистскую компанию против этого зажиточного слоя.

Такая пропагандистская компания против байства разворачивается на страницах газеты «Кызыл Ойрот» на алтайском языке (в Горном Алтае на национальном языке с 1922 г. выходила газета «Кызыл Солын Табыш», название которой в переводе звучит как «Красные новости». В 1923 г. эту газету переименовали в «Ойроттын јери» переводится «Земля Ойротии», а с февраля 1925 г. «Кызыл Ойрот» - «Красная Ойротия» [6]). Надо отметить, в 1920-х гг. в таком отдаленном от центра страны регионе как Ойротская автономная область, газеты являлись основным органом СМИ, которые вели организационную и политико-просветительскую деятельность среди населения. Так же в период НЭПа в автономной области началась политика ликвидации неграмотности. 24 марта 1923 г. Президиум Ойратского обкома РКП (б) принял постановление о создании в области отделения общества «Долой неграмотность» (ОДН). И печатная пресса для населения региона с ростом их грамотности должна была стать еще более доступной [34, с. 83-84].

Газета «Кызыл Ойрот» начинает издаваться с 13 фев- 
раля 1925 г. Она стала единственным периодическим изданием областного уровня, которая печаталась на алтайском языке для коренного населения. И в первом же в своем номере на первой странице опубликовано передовица под названием «Карындаштар, нӧкӧрлӧр!» («Братья, друзья!»). В ней говорится, богатеи - эксплуататорские классы хотят, что бы простой народ оставался не образованным и темным. И в борьбе за светлое будущее эта новая газета «Кызыл Ойрот» будет другом и помощником для алтайского народа. Так же в передовице отмечено, что газета будет заниматься просветительской деятельностью, на ее страницах станут публиковать новости и события, которые происходят в стране и за рубежом, материалы о борьбе рабочих и крестьян против эксплуататорских классов в других странах [30, с. 1]. И уже во втором номере «Кызыл Ойрот» были расставлены приоритеты идеологической борьбы. Так, алтайский драматург Мирон Мундус-Эдоков в газетной публикации под названием «Алтай сӧӧктӱ карындаштар» («Братья алтайцы») пишет, что, на Алтае есть четыре ненасытных чудовищ («дӧрт јеек шиллимир бар»), у них уже нет прежнего влияния и силы, поэтому не надо подвергаться их обману. Далее Мундус-Эдоков перечисляет этих ненасытных чудовищ: на первом месте он ставит байя/кулака «Баштапкы јеек бай - бай/кулак» («Первое ненасытное чудовище - бай/кулак»); остальные чудовища: косматый православный священник («јелтек чачту абыс»), с черными мыслями шаман («кара сагышту кам») и обманщик јарлыкчи (јарлыкчи - священнослужитель алтайской религии бурханизм) [33, с. 2].

Газета «Кызыл Ойрот» на своих страницах представляет байя/кулака в негативном, отталкивающем образе. Здесь бай показан чуждым враждебным элементом для нового Советского общества. Он эксплуататор, хитрый обманщик, жадный и хищный мироед, который хочет жить как раньше при царской власти $[18$, с. 1; 16, с. 2; 1 , с. $2 ; 25$, с. 4; 41, с. $2 ; 37$, с. 2; 5; 7, с. 3]. Так же в газете печатаются материалы, которые могут способствовать обретению экономической независимости бедноты от зажиточных слоев. Например, печатаются публикации о том, что беднякам не обязательно по старинке наниматься к байям. Они могут обратиться в Комитет Взаимопомощи (или крестьянские общества взаимопомощи массовые общественные организации в Советской России и СССР, созданные для оказания экономической поддержки беднякам и семьям красноармейцев) и им окажут поддержку. Например, помогут получить ссуду для приобретения сельскохозяйственных орудий или инвентаря, приобрести семена во время посадки урожая и т.д. или взять кредит в банке [3, с. 2; 20, с. 1; 2, с. 1; 21, с. 3].

Для усиления противоречий между беднотой и зажиточными слоями в газете печатаются материалы о том, что байи продолжают плохо относятся к неимущим слоям. Например, в апрельском номере за 1926 г. сель- кором описан случай, когда известный в Горном Алтае бай Аргымай Кульджин не почтительно отнесся к своему слуге. Так, во время собрания в исполкоме Онгудайского аймака вошел слуга (в материале газеты он отмечен термином - кӧдӧчи - прислужник - Э,Т.) этого байя и сел на свободное место. За ним в помещение вошел Аргымай Кульджин. В исполкоме не оказалось свободных мест, и бай потребовал, чтобы его слуга уступил ему место, что незамедлительно было сделано слугой. Уступив свое сидячее место, сам он сразу ушел с собрания. Этот случай был замечен селькором «Кызыл Ойрот» и описан в газете под названием «Јоктууны кижее бодобойтон емее» («Бедняка за человека не считают») [41, с. 2]. В целом, здесь можно сказать конфликт старого традиционного мировоззрения и новых веяний в стране. С традиционного мировоззрения слуга даже виноват, что сел прежде хозяина. А хозяин слуги Аргымай Кулджин один из богатейших алтайцев в царское время, зажиточным он оставался и в рассматриваемый период. И не прилично, если он будет стоять на собрании. Но в стране новое время, где конституционно отменено эксплуатация человека человеком, а у этого байя всё еще есть слуга.

Надо отметить, часто в своих публикациях газета заостряла внимание, если к беднякам и батракам из-за их неимущего положения плохо относились в повседневной жизни и когда их права притеснялись в повседневной жизни. Например, в материале газеты за август месяц 1925 г. говорится, что в торговом кооперативе «Монгол Госторг» в с. Кош-Агач приказчики не уделяют внимание беднякам из-за их плохой покупательной способности. Далее селькор пишет, что эти приказчики (напечатаны их фамилии) привыкли торговать по старинке, когда почтительно относились к богачам и плохо к беднякам. И если они так будут вести и впредь, то лучше их уволить с работы [28, с. 2; 32, с. 2]. Другой пример, в январском номере газеты за 1927 г. опубликован материал о том, что член сельского Совета Е.М. (Чакырская ячейка Шебалинского аймака) неуважительно относится к беднякам, и что такое поведение этого человека надо пресекать. Сам печатный материал в газету был подан от Бешпельтирской ячейки сельского Совета (Шебалинского аймака) [36, с. 4].

В исследуемый период на странице номеров «Кызыл Ойрот» печатаются материалы, как беднякам отстаивать свои права, если возникают спорные вопросы с байями. Например, в газете появляются публикации, где описаны споры из-за землепользования между байями с одной стороны и бедняками с другой [8, с. 2]. Соответственно в таких случаях газета всегда выступала на стороне последних. Так, в июльском номере за 1925 г. отмечено, что в местности Кырлык Усть-Канского аймака байи большие участки земли огородили под покосы. Местные бедняки хотят посадить зерно, но земля огорожена. Далее в газетном материале говорится, что по Советским законам, 
частной собственности не землю как для байев, так и для бедняков нет. И если люди хотят выращивать зерно, то пусть идут в местный Сельсовет, где их проблему должны решить положительно. Так как участки, где можно выращивать зерно под них и должны использоваться. И в конце публикации отмечено, почему такие незаконности связанные с захватом земель байев допускает местные члены Советов [40, с. 2].

В целом газетные материалы, связанные с землепользованием и спорами по этому вопросу, опубликованы как инструкция к действию бедным слоям алтайского общества. В таких газетных публикациях особо отмечено, что для решения спорных вопросов они должны обращаться в местные сельские Советы, крестьянские комитеты общественной взаимопомощи, профсоюзы, например «Всеработземлес» - профсоюз сельскохозяйственных и лесных рабочих [18, с. 1; 9, с. 1; 14, с. 1]. Если беднякам, возникшие спорные вопросы удается решить в свою пользу, то такой материал в газете подается как торжество справедливости [29, с. 2].

Чтобы экономически ухудшить зажиточные хозяйства, в газетах стали печатать материал о том, что нужно отказывать байям в обычае взаимопомощи - помочи (или «помыш, момыш» у алтайцев - Э.Т.). Суть обычая состояла в совместной неоплачиваемой трудовой деятельности соседей и родственников для завершения у отдельных хозяев срочной работы. Например, часто зажиточным хозяйствам, имеющие большое количество скота, приходилось организовывать помочи во время покоса. Желающих на такие работы было достаточно, потому что помочь не обходился без обильного угощения. Так же каждый участник таких работ надеялся на взаимность, которая ему будет оказана, если он попросит помощь. И в «Кызыл Ойрот» стали печатать публикации, где селькоры выступали против оказания помочи байям. Например, в февральском номере за 1927 г. отмечено, что помочи выгодны для байства, они обманывают бедняков, заставляют на себя работать. А беднякам лучше объединиться и самим помогать друг другу [21, с. 3; 13, с. $2 ; 12$, с. 4].

На страницах газеты всё чаще публикуются материалы, в которых призывают батраков, бедняков и середняков объединится в единый союз. И одной из главных задач этого союза активное участие на выборах в сельские советы, с целью не допустить туда байев/кулаков [24, с. 1; 43, с. 1]. Например, в декабрьском номере за 1926 г. напечатан материал, который призывает больше не голосовать за байев, которым удалось скрыть свое прошлое и были выбраны в местные Советы [11, с. 2; 36, с. 4]. Так, в январском номере газеты за 1927 г. на первой странице в передовице крупными буквами напечатано «Батрактардын, јоктулардын, орто јаткардардын
Советарды езентик болзын!» («Да здравствует Совет батраков, бедняков и середняков!») [10, с. 1]. В этом же номере газеты в публикации «Јамулылурды кандый кижи тудар» («Кто должен выбирать представителей в сельсоветы») отмечено, что в депутаты сельсоветов нельзя выбирать байев которые живут за счет эксплуатации труда батраков и бедняков [19, с.1]. В некоторых номерах газет были изображены карикатурные рисунки тех, кого не стоит выбирать в Советы: байа/кулака, бывших урядников царской полиции, служителей культа и лишенных избирательных прав [39, с. 3; 38, с. 4].

Партийные органы стали бедняков и середняков включать в налоговые комиссии с целью противодействия байству в сокрытии данных о своем имуществе. И в августовском номере «Кызыл Ойроте» за 1927 г. напечатан материал, что бедняки и середняки должны участвовать в налоговой комиссии. Они должны не дать байям спрятать облагаемый налогом скот. Этот налог нужен для народа, собранные деньги пойдут на стройку школ, больниц и т.д. [23, с. 1]. В декабрьском номере за 1926 г. даже были напечатаны фамилии с именами байев Кырлыкского сельсовета Усть-Канского аймака, которые были оштрафованы за сокрытие численности своего скота $[4$, с. 2].

Таким образом, в период НЭПа в Ойротской автономной области партийные органы развернули идеологическую борьбу против байства на страницах газеты «Кызыл Ойрот». В публикациях газеты бай/кулак представлен в негативном, отталкивающем образе. Бай - это чуждый враждебный элемент для нового Советского общества, который хочет жить за счет труда бедняков как при царской власти.

В рамках этой борьбы в газете печатаются материалы, которые способствовали экономической независимости алтайской бедноты от эксплуатации зажиточных слоев. Так же в газете выпускается материал, дающий знание бедноте, как противостоять байям при возникновении спорных вопросов.

Через газету партийные органы вели большую агитационно-пропагандистскую работу. Так, в исследуемый период на страницах «Кызыл Ойрот» публикуется материал, направленный на гражданскую и политическую активность бедноты. На её страницах всё чаще печатаются материалы, в которых призывают батраков, бедняков и середняков объединиться в единый союз с целью не допущения байев/кулаков в состав членов сельского Совета.

Если рассматривать в целом, газета «Кызыл Ойрот» находились в идеологическом поле, под жесточайшим контролем и цензурой. Газета формировала общественное мнение в духе марксистско-ленинской идеологии. 


\section{ЛИТЕРАТУРА}

1. 24 кӧстӱ кӧсмӧкчи кижи. Байлар јендегенче // Кызыл Ойрот. 1925. 16 сент. (на алт. яз.).

2. А И. Акча берип турган кредиттердин ааи // Кызыл Ойрот. 1925. - 28 окт. (на алт. яз.).

3. Ак Айры кижизи. СельКККОВ-тор текши андый болор керек // Кызыл Ойрот. 1925. 10 окт. (на алт. яз.).

4. Аладяков. Мал јажирган улуска кайрал болды // Кызыл Ойрот. - 1926. 18 дек. (на алт. яз.).

5. Алтай. Комсомолды јаман кӧрӱпјят // Кызл Ойрот. 1927. [Электронный ресурс] URL: http://185.66.29.234/bd/gazeti.php?categorie=3\&URL=Kizil\%20 Oyrot/1927/63/ (дата обращения: 02.10.2021). (на алт. яз.).

6. Алтайдын Чолмоны [Электронный ресурc] URL: https://ru.wikipedia.org/wiki/Алтайдын_Чолмоны (дата обращения: 02.06.2021).

7. Алтайдын јалчы-батрак улустары // Кызл Ойрот. 1928. 4 коч. (февр.) (на алт. яз.).

8. Апоятов. Байлардын кылыгы // Кызыл Ойрот. 1925. 1 май. (на алт. яз.).

9. Апоятов. Селсоветтар бу керекти кичеегер! // Кызыл Ойрот. 1925. 9 май. (на алт. яз.).

10. Батрактардын, јоктулардын, орто јаткардардын Советарды езентик болзын! // Кызыл Ойрот. 1927. 8 янв. (на алт. яз.).

11. Бедюров Тодош Я. Советке кандый улус тудаар // Кызл Ойрот. 1926. 15 дек. (на алт. яз.).

12. Бедюров. Алтай улустын помыч едери чыгымду // Кызыл Ойрот. 1927. 17 сент. (на алт. яз.).

13. Бедюров. Помшты јок едер керек // Кызыл Ойрот. 1926. 15 сен. (на алт. яз.).

14. Бистий эм тургуза иштейтен керек // Кызыл Ойрот. 1926. 17 февр. (на алт. яз.).

15. Государственный архив Республики Алтай (ГАРА). ГАРА. Ф. 1. Оп. 1. Д. 581.

16. Дади куш Кижизи. Ачап бӧӧрӱ ошкош // Кызыл Ойрот. 1925. 13 нояб. (на алт. яз.).

17. Демидов В.А. К социализму, минуя капитализм. Новосибирск: Наука, 1970. 224 с.

18. Јалга јӱрген улысты ундыбагар // Кызл Ойрот. 1925. 20 март. (на алт. яз.).

19. Јамулылурды кандый кижи тудар // Кызыл Ойрот. 1927. 8 янв. (на алт. яз.).

20. Јаны ККОВ јамылуларнын кижи // Кызыл Ойрот. 1926. 24 март. (на алт. яз.).

21. Јокту кижи кредит таген болушты кайдан алар, канайда алар // Кызл Ойрот. 1927. 17 февр. (на алт. яз.).

22. Јокту кижи. Јоктудын кӱчи-ле јадат // Кызл Ойрот. 1927. 19 февр. (на алт. яз.).

23. Јоктула тал орто јаткандар, деремнедеги Совет бакарууд ын ишдӱӱ. Јокту-ла орто јаткандар, налогтын комиссиялардын ижине болуш едер улустары // Кызыл Ойрот. 1927. 6 кур. (авг.) (на алт. яз.).

24. Јоктуларга бэш јакты куучин // Кызл Ойрот. 1927. 17 февр. (на алт. яз.).

25. Јурт кижи. Байда болзо мекечи // Кызл Ойрот. 1926. 22 май. (на алт. яз.).

26. Екеев Н.В. Социально-экономическое развитие деревни Горного Алтая в 1920-х годах. Горно-Алтайск: Горно-Алтайское отделение Алтайского книжного издательства, 1988. 208 с.

27. История Горного Алтая. В трех томах. Том второй. 1990-1945 гг. /Под ред. Н.М. Екеевой, Н.Ф. Иванцовой. Бийск, 2000. 223 с.

28. Каланчинов М. Байдын санаазы эмдее јаан // Кызл Ойрот. 1925. 22 авг. (на алт. яз.).

29. Карачаков. Јоктулар јердї болды // Кызл Ойрот. 1926. 21 окт. (на алт. яз.).

30. Карындаштар, нӧкӧрлӧр // Кызыл Ойрот. 1925. 13 февр. (на алт. яз.).

31. Конституция (основной закон) Российской Социалистической Федеративной Советской Республики : опубликована в № 151 "Известий Всерос. центр. исполн. комитета" от 19 июля 1918 г. - Москва : Изд-во Всерос. центр. исполн. ком. Р., С., К. и К. депутатов, 1918. 31 с.

32. Кӧргӧн кижи. Андый кылык јарабас емей // Кызл Ойрот. 1925. 3 апр. (на алт. яз.).

33. Мундус-Эдоков М. Алтай сӧӧктӱ карындаштар // Кызыл Ойрот. 1925. 20 февр. (на алт. яз.).

34. Очерки истории Горно-Алтайской областной организации КПсС / Гл. ред. Н.С. Лазебный. Горно-Алтайск: Горно-Алтайское отделение Алтайского книжного издательства, 1971. 394 с.

35. Очерки по истории Горно-Алтайской автономной области / Л.П. Потапов. Горно-Алтайск: Горно-Алтайское отделение Алтайского книжного издательства, $1973.540 \mathrm{C}$

36. Саденчиков К. Маркитанов ӧӧинен ӧтпӧс керек // Кызл Ойрот. -1927.8 янв. (на алт. яз.).

37. Сандычиков А. Озогызыла емдигизи. Јалчы кижинин куучыны // Кызл Ойрот. 1927. 9 февр. (на алт. яз.).

38. Сельсоветке тудулбас улус: ... // Кызыл Ойрот. 1927. 22 янв. (на алт. яз.).

39. Совет кемди тутпас: ... // Кызыл Ойрот. 1927. 15 янв. (на алт. яз.).

40. Табышев. Сууру. Јердин кереги // Кызл Ойрот. 1925. 1 июль. (на алт. яз.).

41. Тайбон. Јоктууны кижее бодобойтон емее // Кызыл Ойрот. 1926. 14 апр. (на алт. яз.).

42. Эдоков И.П. Коллективизация в Горном Алтае. Горно-Алтайск: Горно-Алтайское отделение Алтайского книжного издательства, 1987. 244 с.

43. Ячекалардын кичеейтен кереги // Кызл Ойрот. 1926. 21 апр. (на алт. яз.). 